\title{
Perioperative complications and long term consequences of sacrospinous ligament fixation and abdominal sacrocolpopexy
}

\section{Sakrospinöz ligament fiksasyonu ve abdominal sakrokolpopeksi'nin perioperatif komplikasyonları ve uzun dönem sonuçları}

\author{
Ertan Zam¹, Büllent Duran²
}

A Private Clinic Obstetrics and Gynecology, Alanya, Turkey

2 Adatip Private Hospital, Obstetrics and Gynecology, IVF Centre, Sakarya, Turkey

Corresponding author: Ertan Zan, MD, A Private Clinic Obstetrics and Gynecology, Alanya, Turkey

E-mail: drertanzan@hotmail.com

Received/Accepted: November 21,2019/December 31,2019

Conflict of interest: There is not a conflict of interest.

\section{SUMMARY}

Objective: This retrospective study was done for comparison of early complications and long term consequences sacrospinous fixation (SSF) and abdominal sacrocolpopexy.

Method: This sutdy was performed retrospectively from july 2015 to september 2017. Fifty four women were included the study. Forty women underwent vaginal sacrospinous fixation following vaginal hysterectomy for total prolapse and vaginal vault repair. Fourteen women underwent abdominal sacrocolpopexy procedure for preventing vaginal vault prolapsus. Perioperative complications were defined as any complication occurs during surgery or at the first 6 weeks postoperatively.

Results: All patients were followed up for 6 weeks, 3,6 . and $12^{\text {th }}$ months postoperatively. Intraoperative presacral venous bleeding during the abdominal sacrocolpopexy were detected in two subjects. They were treated with applying pressure with gauze pad about 10 minutes. Vesical injury occured in one subject during the vaginal hysterectomy which was repaired easily via vaginally. The mean duration of follow-up was 12 months. Recurrent vaginal vault prolapses and cystocele in two cases, rectosel in one case and stress incontinence in two cases were detected following SFF.

Conclusions: SSF can be used as an adjunctive and easy procedure after vaginal hysterectomy in pelvic organ prolapse. The advantage of the operation is avoiding of the laparatomy and preserve the functionality of the vagina. Abdominal sacrocolpopexy was associated with a higher succes of operative result.

Keywords: Pelvic organ prolapse, abdominal sacrocolpopexy, sacrospinous fixation, vaginal vault prolapse.

\author{
(iD) Ertan Zan \\ (D) Bülent Duran
}

ORCID IDs of the authors:

E.Z. 0000-0002-8047-8893

B.D. $0000-0002-7090-8183$

\section{ÖZET}

Amaç: $\mathrm{Bu}$ retrospektif çalışma iki farklı operatif yöntemin erken komplikasyonlarıyla uzun dönemli sonuçlarını karşılaștırmak amaciyla yapıld1.

Yöntem: Çalışma,Temmuz 2015 ile Eylül 2017 arasında 54 hasta üzerinde retrospektif olarak yapılmıştır. 40 kadına vajinal histerektomi sonrası kafi fikse etmek amacıyla sakrospinöz fiksasyon operasyonu yapıldı. Daha önce opere 
edilen ve vajinal kaf prolapsusu olan 14 kadına da abdominal sakrokolpopeksi uygulandı. Operasyon sırasında ve post operatif ilk 6 haftada karşılaşılan komplikasyonlar perioperatif olarak adlandıııldı.

Bulgular: Perioperatif olarak 2 abdominal sakrokolpopeksi vakasında sakrum ön yüzünde venöz kanama oldu. 10 dakika süreyle gaz spanç tamponu ile kanama durduruldu. Vajinal histerektomi yapılan olgulardan bir tanesinde mesane perfore edildi. Perforasyon hemen tamir edildi. Sonda post operatif 10 gün tutuldu. İki vakada vajinal kaf prolapsusu yeniden ortaya çıktı. 2 vakada sistosel,bir vakada rektosel izlendi. Vajinal SSF yapılan hastalardan 2 tanesinde stres inkontinans ortaya çıtı.

Sonuç: Vajinal SSF operasyonu prolapsus nedeniyle ameliyat edilen hastalarda uygulanabilecek kolay ve yararlı bir operasyondur. Operasyonun avantajı laparatomiden kaçınmaktır. Ayrıca daha fonksiyonel bir vajina da ortaya çıkmaktadır. Teknik olarak daha zor olmakla birlikte abdominal yolla meş kullanılarak yapılan sakrokolpopeksinin uzun dönem başarısı daha yüksektir.

Anahtar sözcükler: Abdominal sakrokolpopeksi, pelvik organ prolapsusu sakrospinöz fiksasyon, vajen kaf prolapsusu.

\section{INTRODUCTION}

Pelvic organ prolapse (POP) affects almost half of older women. In women over the age of 50, approximately $30-50 \%$ deteriorates the quality of life. After the age of 70-80, approximately 10$12 \%$ of women are operated due to pelvic organ prolapse $^{1}$. There are many reasons for the deterioration of the pelvic floor. Especially vaginal deliveries, multiparity, difficult and intervention deliveries, prolonged labor and delivery of large for gestational age babies are among these reasons. Uterovaginal prolapse is a complex disorder. It is also necessary to recognize and correct the concomitant disorders including cystocele, rectocele, enterocele and stress incontinence ${ }^{2}$.

Surgical correction of pelvic organ prolapse can be performed by laparotomy, laparascopy or vaginal route. Recently, laparoscopic correction with or without mesh are performed. The most appropriate operation should be to correct the specific disorder. The age of the patient, other accompanying diseases, previous prolapse corrective operations and even the desire for future fertility are also important in the choice of the operation. The surgeon's skill and knowledge of pelvic flooring will also affect the success of the operation.

SSF is an easy and useful operation. Leaves an adequate vaginal length after surgery. Since the right side of the patient is usually used, the vaginal axis shifts slightly to the right. The cuff is usually hung on the right side of the sacrospinous ligament. For this purpose, prolene suture is generally used. A deep episiotomy-like incision is made in the right lateral area and the retroperitoneal area is entered and the sacrospinous ligament is present starting from the ischial spine to the coccyx. Using BreiskyNavratil retractors, one or two sutures are passed $2-3 \mathrm{~cm}$ lateral to the ischial spin. Sutures are passed submucosally into the vaginal cuff. The sutures fix the vaginal cuff over the sacrospinous ligament. The vagina is closed as if the episiotomy repairs it. It is an easy and short-term operation. In the meantime, other defects in the vagina can be corrected ${ }^{3}$.

Abdominal sacrocolpopexy is generally preferred in cases of recurrent prolapse. It can be performed laparoscopically, but the experience and skill of the surgeon is very important for the laparoscopic route. In particular, fixing the mesh fixed to the vaginal cuff $2-3 \mathrm{~cm}$ below the promontorium on the anterior surface of the sacrum provides a more anatomical correction. The associated cystocele and rectocele are greatly improved. Enterocele and rectocele are anatomically corrected by closing the Douglas cavity. If necessary, the vagina is fixed to the whitwe-line line on the side wall of the pelvis. In this way, anatomical correction is much better ${ }^{4}$.

The aim of this study was to compare the early and late results of vaginal SSF operation and abdominal sacrocolpopexy

\section{MATERIAL AND METHODS}

The patients who admitted to Adatıp Hospital Obstetrics outpatient clinic, who underwent vaginal hysterectomy plus SSF or abdominal sacrocolpopexy with mesh were evaluated retrospectively. Forty cases of SSF operated between 2015-2017 and 14 cases of abdominal sacrocolpopexy operated for recurrent prolapse were retrospectively compared.

Fourty patients in the vaginal SSF group and 14 patients in the abdominal sacrocolpopexy group were included in the study. Age, weight, parity, previous surgery, operation time, mean blood loss and transfusion requirements were recorded. Postoperative results were divided into three as complete recovery, partial recovery or failure. Fever, wound infection, mean hospital stay, stress urinary incontinence complaints were recorded as complications. 
Prolapse classification was performed according to the POP-Q system (11). SSF was applied to the right side using etibond suture. Polypropylene mesh and etibond sutures were used in abdominal sacrocolpopexy. The mesh was fixed to the vaginal cuff with 4 sutures and 2 etibond sutures were hung on the anterior face of the sacrum. The mesh was placed so that it was not taut. He was covered with vicryl. Douglas obliteration was applied to all patients by Halban or Moskowitch method.

Written informed consent was obtained from all patients. Corrective operations were performed for those with significant cystocele or rectocele. Urodynamic tests were performed for stress incontinence. TOT sling (with Obturix) was applied to 3 patients with genuine stress urinary incontinence. All three cases were in the vaginal hysterectomy group. All patients were evaluated preoperatively and postoperatively by the same urogynecologist.

\section{Statistical Analysis}

The results were recorded as healing, partial improvement, or failure at the last follow-up. POP-Q stage 0-1 cases without complaints were accepted as healing. POP-Q stage 2 cases without complaints were accepted as partial improvement. Patients with complaints of POP-Q stage 3-4 were considered to be unsuccessful. Data were evaluated using Fisher's sex test and chi-square test. $\mathrm{P}<0.05$ was considered statistically significant.

\section{RESULTS}

All patients were followed up for 6 weeks, 3, 6, and $12^{\text {th }}$ months postoperatively. The age of the vaginal SSF group was lower than that of the abdominal sacropexy group. Intraoperative presacral venous bleeding during the abdominal sacrocolpopexy were detected in two subjects. They were treated with applying pressure with gauze pad about 10 minutes. Vesical injury occured in one subject during the vaginal hysterectomy which was repaired easiliy via vaginally. Recurrent vaginal vault prolapses and cystocele in two cases, rectosel in one case and stress incontinence in two cases were detected following SFF.

No damage was made to the pudendal vessels or nerves in patients undergoing vaginal SSF. Only one patient who had undergone TOT had bleeding that required transfusion. This patient received 2 units of erythrocyte suspension. In the abdominal sacropexy group, two patients had an average blood loss of $350 \mathrm{ml}$. Mean blood loss was less in the vaginal SSF group than in the sacropexi group. One patient in the vaginal SSF group had peroperative bladder injury and the bladder was primarily repaired. Vaginal cuff infection developed in 2 of the patients who underwent vaginal SSF. Urinary infection was detected in 6 SSF patients. The vaginal ssf group was discharged on average in 2 days. This period is 5 days in the abdominal sacropexy group. The vaginal SSF operation was completed in approximately 10 minutes (5-15 $\mathrm{min}$ ).

\section{DISCUSSION}

Pelvic organ prolapse can be treated abdominally or vaginally. Prolapse surgery brings success and failures depending on the experience and experience of the physician. Vaginal surgery is preferred because it is easier and faster. Abdominal prolapse surgery is preferred in cases of failed or recurrent prolapse. In addition to the experience of the physician, the patient's age, weight and previous pelvic surgeries play an important role in determining the success of the surgical procedure.

In this study, we compared the early and late outcomes of two different operations in prolapse surgery. We found that right unilateral SSF operation is a good option for patients with POP$\mathrm{Q}$ stages 1,2,3. The main complication of this operation was back pain, gluteal and groin pain. We also found that this pain disappeared in the 2nd month after the operation. Vaginal hysterectomy and SSF operation time was significantly shorter than abdominal group. These results are consistent with the literature . $^{5}$

We detected recurrent cuff prolapse in 3 patients in the SSF group at the last follow-up. No recurrence was observed in the abdominal sacropexy group at the last visit. In our study, operative time and blood loss were higher in patients with abdominal sacrocolpopexy. There are similar results in the literature ${ }^{6,7}$. There was no difference between the two groups in terms of fever, wound infection and urinary infection. The short duration of vaginal operations and low complication rates indicate that they are a good alternative for prolapse surgery.

It is an important handicap that recurrence cases are more common in SFF group than abdominal sacropexy group. The most important reason for this may be the unilateral operation. However, it does not seem logical to make a bilateral SFF. Because SFF from both the right and left vaginal wall is technically difficult and carries some complications. In addition to being very meticulous during the surgical procedure, good 
patient care in the postoperative period will increase the success rates. The patient's special effort against cough and weight in the postoperative period will also contribute to the success rates of SFF.

\section{REFERENCES}

1. Chou LY, Chang DY, Sheu BC, et al. Clinical outcome of transvaginal sacrospinous fixation with theVeronik is ligature carrier in genitalprolapse. Eur $\mathbf{J}$ ObstetGynecolReprodBiol. 2010;152(1):108-110.

2. Demirci F, Özdemir I, Somunkıran A, et al. Perioperative complications in abdominal sacrocolpopexy and vaginal sacrospinous ligament fixation procedures. IntUrogynecol J. 2007; 18: 257-261.
3. Uzoma A, Farag KA. Vaginalvaultprolapse. ObstetGynecolInt. 2009; 275621. Epub2009 Aug 11.

4. Beer M, Kuhn A. Surgical techniquies for vault prolapse: a review of the literatüre. Eur J Obstet Gynecol Reprod Biol. 2005;119(2):144-155.

5. BumpRc, Mattiasson A, Bo K, et al. The standardization of terminology of female pelvic organ prolapse and pelvic flor dysfunction. Am J ObstetGynecol 1996; 175:10-17

6. PengP,Zhu L, Lang JH, et al. Unilateral sacrospinous ligament fixation for treatment of genital prolapse. ChinMed J (engl). 2010;123(15):1995-1998.

7. Maloney JC, DuntonCJ, Smith K. Repair of vaginal vault prolapse with abdominal sacropexy. J ReprodMed 1990; 35: 6-10. 